\title{
HOW CAN THE SURGE OF SECTARIAN INTOLERANCE IN PAKISTAN BE TACKLED? BRIDGING THE WIDENING DIVIDE Musferah Mehfooz $^{1 *}$, Safia Parveen ${ }^{2}$ \\ ${ }^{1 *}$ Assistant Professor, Department of Humanities, COMSATS University Islamabad, Lahore, Pakistan; ${ }^{2}$ MS, Scholar, Department of Humanities, COMSATS University Islamabad, Lahore, Pakistan. \\ Email: "musferahmehfooz@ cuilahore.edu.pk
} Article History: Received on $15^{\text {th }}$ May 2021, Revised on $11^{\text {th }}$ June 2021, Published on $18^{\text {th }}$ June 2021

\section{Abstract}

Problem and aim of the study: This article deals with the causes of the scary rise of sectarian Intolerance, violence, and prejudices in Pakistan. This article also investigates that how sectarian intolerance causes violence in society and what strategies should imply to curtail sectarianism from society?

Research methods: The research is qualitative, and applies the inductive and deductive methodology to the collected data. The data has been derived from the South Asian Terrorism Portal and to analyze the authenticity the author has collected the shared information from published articles, researches, and government official website that provide the statistics about violence and terrorism.

Main findings: The study concludes by arguing the dire need for the promulgation and dissemination of inclusive thoughts for attaining a tolerant society free from sectarian intolerance because the implications of sectarian violence are a great threat to the peace process in the country.

Application of the study: This study has significant implications from both a theoretical and a realistic perspective. The present study would be useful for policy-makers, to curtail the sectarianism in State. Therefore, the banning of sectarian speeches, sectarian literature, has been strongly suggested. The government should place a moratorium on the printing of sectarian literature for sectarian unity. The study also has tried to make realize to the state actors, including security forces and intelligence agencies, to avoid blame foreign involvement in sectarian polarization and why they ignore the fault lines destabilizing Pakistan's social fabric since Pakistan's inception. Therefore, the study would doubtlessly help decrease unpleasant incidents and reduce religious fanaticism.

Originality and novelty of the study: This is the fact that in the existing literature the least attention has been given to sectarianism in Pakistan. The present study aims to deals with the social, religious, and political aspects of sectarian violence. Therefore, this is the first study that has investigated sectarian violence by exploring the issue of sectarianism from a social, religious, and political perspective.

Keywords: Sectarian Intolerance, Religion, Violence, State.

\section{INTRODUCTION}

The flames of sectarianism kindle in most societies of the world and often it becomes a complex issue in numerous cultures and societies. Pakistan is also among those where sectarianism has turned into a complex issue which proved not only the major hindrance to its development but also a threat to its integration. Sectarianism has become a national concern by the rapid expansion of its tentacles throughout Pakistan, and a greater source of violence in society (Abbas \& Syed, 2021). Sectarianism is an issue that has badly damaged society (Asma Khan, 2017). Sunni and Shia are the two main sects of Islam. It is unfortunate that historically, sects and subsects hold extremist views against each other. Majeed \& Hashmi (2014) define it as "the strong support for a particular religious or political group, especially when this leads to violence between different groups and in such a way as to consider others' views completely wrong and their followers as infidels." Therefore, sectarianism means the philosophy of a group construction is dissimilar and different from others and can be defined as "the intolerant attitude of a particular school of thought towards others, which divides different segments of society into antagonistic groups and creates hatred between them based on faith and belief system" (Ahmar, 2010).

THE RATIONALE OF THE STUDY: Sectarianism is spreading rapidly its tentacles all around the country. Even, it has hit those areas which were free of sectarian strives and getting violent day by day. This can be solved by making determined efforts to deal with sectarian intolerance in Pakistan. It can be a focus on some of making suitable policies to abolish this element from every area. It can consist of different steps that can help it eliminate at the initial level by tackle rising violence. Although it is a difficult task it's not impossible to work (Mahsood \& Muhammad, 2017). Therefore, it is indispensable to address the root causes of sectarian intolerance promptly to contain the issue.

Thus, the present study aimed to address that Sectarian Intolerance is causing a scary rise of violence in Pakistan.

\section{LITERATURE REVIEW}

Sectarianism in Pakistan is a complex phenomenon and it is not easy to analyze the basic factors of the conflict among sects that hinders peace settlement in the state (Abbas, 2015). Background of the sectarian divide in Pakistan and how the confessional differentiation between Sunni and Shitte communities affects the country and society; religious extremism 
and intolerance lead to sectarian violence in Pakistan (Malik et al., 2019). Pakistan has failed to eliminate sectarian conflicts, social polarization from its territory (yder et al., 2015). Mainly foreign forces are involved to vent the feelings of hatred among the different religious groups (Khan, 2005). Wibisono, Louis, \& Jetten, (2019) state that sectarian clashes exploded throughout the last three decades between Shia and Sunni Muslims in Jhang. According to Jhang District Police Officer (DPO)'s official records, approximately 123 sectarian clashes were registered in various police stations from 1989 to 2002 . Abbas, \& Syed relate the issues to religious division, political power, and ethnic identities (Abbas, \& Syed, 2021). Nearly about 3059 incidents of sectarian violence have occurred since 1989 in which more than 5000 people were killed (Bakhsh et al., 2020). Smith (2014), stated that the Islamic revolution in Iran, and the Afghan war are some of the contributing factors in the emergence of sectarian violence. The Human Rights Commission Report of Pakistan states that over 200 sectarian terrorist attacks were in 2013 (Human Rights Commission of Pakistan, 2014). According to Pakistan's National Commission for Human Rights (NCHR) "With a population of about 600,000 in Quetta, the community, whose physical appearance makes them easy targets, has been targeted in a sustained campaign of murders and bombings that have claimed at least 509 lives since 2013" (Asad Hashim, 2018). In 2013, "Pakistan had the highest possible score on the social hostilities involving religions index, which measures acts of religious hostility by private individuals, organizations, and social groups (Kfir, 2014). This includes religion-related armed conflict or terrorism, mob or sectarian violence, harassment over attire for religious reasons, and other religion-related intimidation or abuse" (Grim, 2014). Due to this uncertain situation, the state has failed to maintain a law-and-order situation, especially in the sectarian-based areas of Pakistan. Sufi shrines, Mosques, and Madrassas are continuously targeted by sectarian extremists (Naaz, 2019). Pakistan's National Security Policy 2014-2018 was cited as saying, "Pakistan is confronting genuine conventional and non-customary dangers of rough radicalism, sectarianism, terrorism, and militancy." While discussing sectarianism, Mishra, (2004) claims that violent religious conflict exists between Shia and Sunni Muslims in Pakistan. The bar chart below shows the data on fatalities in terrorist violence in Pakistan from 20002019. Each year's the fatalities due to terrorist violence increased from 2000 till 2009, and achieved their peak in 2009.

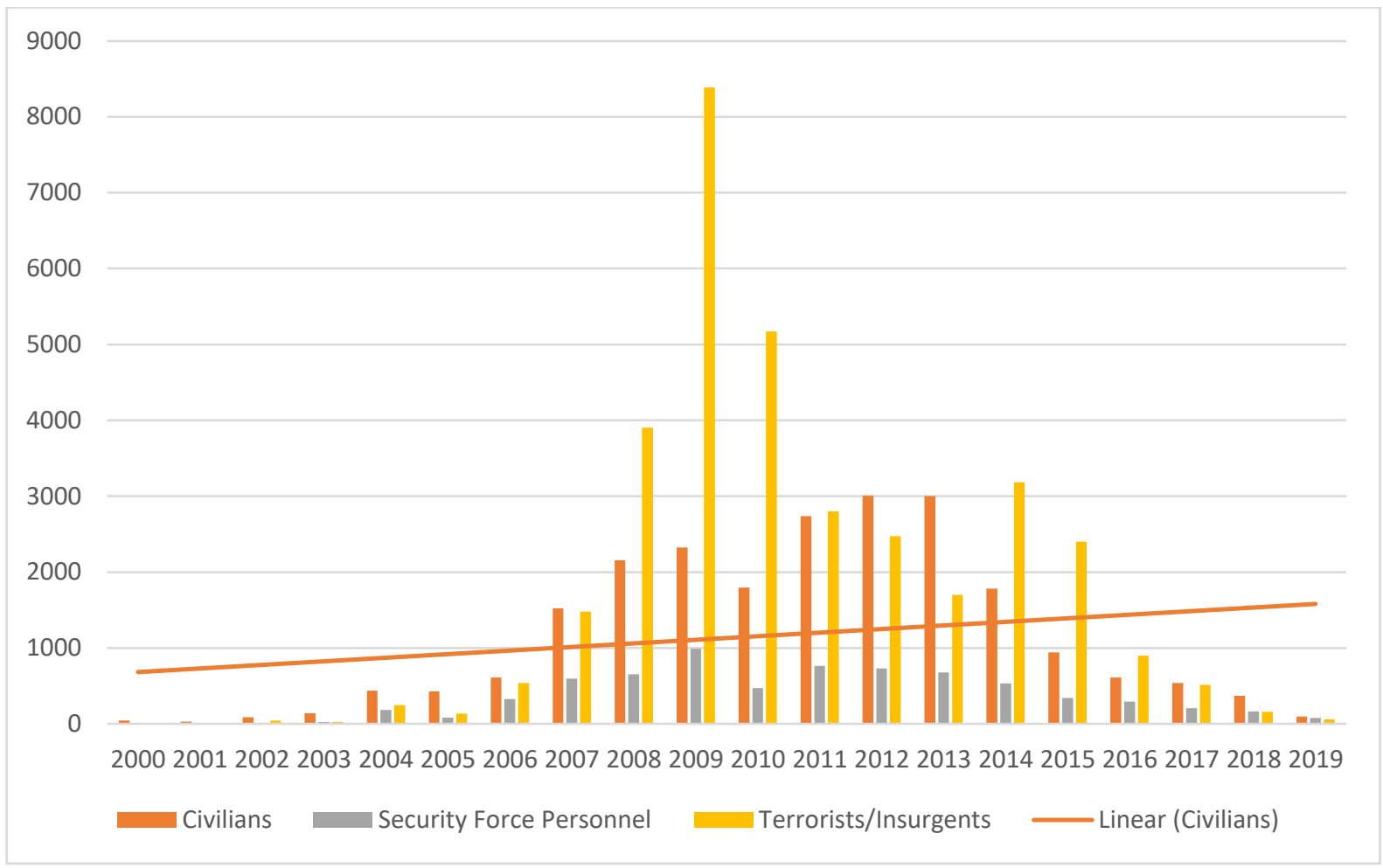

Figure 1: Sectarian violence in Pakistan (January 2000-December 2019)

Source: "South Asian Terrorism Portal"*

\section{METHODOLOGY}

The research was designed qualitatively. The data has been derived from the South Asian Terrorism Portal. The inductive and deductive methodology has been applied to conclude the data objectively.

\section{FINDINGS /DISCUSSION}

In the past, it used to be confined to debates among the sectarian 'Ulama; later, it progressed to hot discussions among

\footnotetext{
${ }^{*}$ South Asian Terrorism Portal, Sectarian Violence in Pakistan, <www.satp.org/satporgtp/ countries/Pakistan/database/sect-killing.htm>, visited on 1 November 2020. 
the masses; hot sectarian discussions riled up emotions to a level where followers of one sect pelted religious processions of the rival sects with stones (Abbas \& Syed, 2021). With the Afghan war for independence from the former USSR's yoke, gun culture took a stronghold in Pakistan, and rival sects started firing at each other's processions. As the Afghan war dragged on, it brought bomb-making expertise to Pakistan, and as a result, sectarian outfits started bombing each other's religious processions. Finally, the most dangerous assassination attempts have begun on processions and gatherings. If the situation goes on, Pakistan's dignity and solidarity may soon be undermined. It is therefore indispensable to do something decisive for resolving the problem. Against this backdrop, the following suggestions are made.

We should introduce education reforms in seminaries' syllabuses to cater to modern life needs (Naveed, Hussain \& Salim, 2011). Modern educational and theological awareness must be offered to students. Computer science, basic science, and other modern subjects will help students to find employment in the market. This initiative not only broadens the students' viewpoints but also eliminates the distance between modernists and traditionalists.

The supreme council should be comprised of 'Ulama from all schools of thought, chosen according to fundamental principles based on freedom of speech and expression, and particularly tolerance for the beliefs of other sects (Shaista \& Shafqat, 2018). Any sect's representative in the Council must exercise complete control upon the adherents of his sect. The floor of the council should also be used to address numerous national problems, especially religious issues (Zaman et al., 2019).

Similarly, sectarian gatherings increase religious fanaticism because it is in these gatherings that adherence to a sect is emphasized. On such occasions, sectarian leaders also demand more and more followers' loyalty to propagate and protect their sectarian ideology. It has been proved that these gatherings and those followers of opposing sects are as powerful as any bomb (Abbas \& Syed, 2021). Therefore, the banning of sectarian speeches has been strongly suggested. It would decrease unpleasant incidents and also reduce religious fanaticism.

It is important to curb the challenge of sectarianism by enforcing Islamic ideology in its true spirit by government machinery and suppressing extremist movements in the best interests of the State (Afzal et al., 2012). The government must begin a plan to ban specifically different terrorist groups, and reforms should be introduced to improve the role of madrasas in society (Shah, 2014). Non-governmental organizations are formed to defend the masses by combating social evils, as sectarianism is a danger to the stability and security of society (Abbas \& Syed, 2021). Therefore, NGOs in different parts of the world should be established to establish sectarian harmony. In any area plagued by sectarian conflict, the NGOs' workers should consist of local religious people of all faiths. The presence of 'Ulama in the NGO staff would also alleviate the general anxiety of 'Ulama and the masses about the derogatory role of NGOs (Waseem et al., 2010).

Several Muslim intellectuals and scholars have sought to stabilize the relations between sects of Muslims. Among these praiseworthy scholars is Shah Wali Ullah (1703-62) from the Sunni school of thought and the Syed Dildar Ali from the Shia school of thought. They rejected the notion of multiple sects in Islam and indicated that only the enemies of Islam would be benefitted from theological conflicts and tensions, which are also aimed at fueling Islam's rifts (Kalin \& Siddiqui, 2014).

Most of our 'Ulama have a sanctimonious nature: there are inconsistencies between what they claim to do to eliminate sectarianism, and what they do. In print and electronic media, 'Ulama talk of Muslim unity. However, they urge their adherents in their private meetings to pursue aggressive actions against other sects (Zaman et al., 2019). This mentality is frustrating. The ruling authorities and concerned departments should monitor these kinds of situations to create awareness to condemn this kind of approach due to the severity of fanaticism and sectarian violence. On the contrary, the 'Ulama will be compelled to come on the right track (Shaista \& Shafqat, 2018).

All sectarian groups and parties which fan sectarian hate should be banned. Their offices need to be locked and their staff and politicians put behind bars. We admit that this strategy or policy would be against the notion of freedom of speech and association, which is necessary to maintain public peace (Majeed \& Hashmi 2014). However, this ban should not be imposed upon nonviolent groups that are not involved in fanning fanaticism.

The Government should place a ban on foreign assistance for sectarian groups to shield Pakistan from this civil war and provide a stable climate (Kashif, 2019). Reduced budgets would discourage them from conducting terrorist operations or printing sectarian literature. There is a dire need to increase the budget for anti-sectarian operations and implement all the proposed strategies by researchers, analysts, and policymakers. It is mostly citizens belonging to the poor class who commit terrorist acts (Siddiqui, 2015). They usually consider this option because of exceeding hardship in their lives, unemployment, and poverty (Basit, 2013).

These individuals can easily be hired for terrorist activity because they already have nothing to do. The government should take steps for the elimination of unemployment and poverty. Besides reducing poverty and unemployment, small business loans and opportunities for jobs should be offered. Undoubtedly it would keep people occupied, and thus they would refrain from sectarian violence (Abbas \& Syed, 2020). The sense of jealousy, envy, and hatred can also be eradicated by work. The government must create job opportunities. Welfare programs should also be implemented to 
eradicate poverty. In addition to socio-economic uplift, these endeavours would create sufficient opportunities for the jobless.

Enough money is reported to have been spent on publishing sectarian literature to protect and propagate sectarian ideologies (Siddiqui, 2015). Besides provocative statements, the mullahs (semi-theologians) also criticize other sects' beliefs on sensitive issues. Emphasis is also put on adopting violent behaviour against other sects.

Religious seminaries belonging to various sects publish their magazines and publications endorsing their sects which creates hatred for the opposite sect's followers. Since the independence of Pakistan in 1947, three hundred religious journals have been published to influence the readers' religious beliefs (Ahmar, 2007). The 'Ulama should collaborate with all sects to create literature that contributes to cordial ties between different sects. The masses of the common citizens should also stop reading sectarian literature. The publishing of sectarian literature must be actively prevented by this joint government battle, Ulama, and the masses (Shaista \& Shafqat, 2018).

\section{CONCLUSION}

The ruling class had never used religion to reinforce the national integration process. Since Pakistan was founded, rulers, especially military leaders, have used religion for their purposes. Various Pakistani rulers have engaged religious groups in sectarian conflict to protect their interests. From 1988 to 2004, sectarian killing was at its height because all the sectarian plants implanted in Zia's era bore fruits in this period. Well-organized and well-trained terrorist groups emerged, and were involved in bomb blasts and killing innocent people. After 9/11, Pakistan's government joined the international coalition against terrorism. However, the government's efforts did not meet with much success, and until now, the ongoing sectarian skirmish is dividing the population of Pakistan with dangerous ramifications.

\section{RECOMMENDATIONS FOR POLICYMAKERS}

The recommendations of the study are based on the uniformity of religious institutions' education. The government should take steps for the elimination of unemployment and poverty. Welfare programs should also be implemented to eradicate poverty. The government should place a moratorium on the printing of sectarian literature for sectarian unity. The publishing of sectarian literature must be actively prevented by this joint government battle, Ulama, and the masses.

\section{LIMITATIONS OF THE STUDY}

The present study has a few limitations, for example, the research was designed qualitatively; therefore, the intensity of the issue demands empirical research to analyze the public approach to curtail the problem. Moreover, this study has focused on the role of religious fanaticism and political parties in the prevalence of sectarian violence while other factors like proxy-war and forging policy have been ignored in this study due to the limited period.

\section{ACKNOWLEDGEMENT}

The authors of this research feel no conflict of interest and declare this research solely their own and the present study is non-funded research.

\section{AUTHORS CONTRIBUTION}

Both the authors have contributed equally to the formation and articulation of this research.

\section{REFERENCES}

1. Abbas, H. (2015). Pakistan's Drift into Extremism: Allah, the Army, and America's War on Terror: Allah, the Army, and America's War on Terror. Routledge. https://doi.org/10.4324/9781315701912

2. Abbas, S. A., \& Syed, S. H. (2021). Sectarian terrorism in Pakistan: Causes, impact and remedies. Journal of Policy Modeling, 43(2), 350-361. https://doi.org/10.1016/j.jpolmod.2020.06.004

3. Afzal, S., Iqbal, H., \& Inayat, M. (2012). Sectarianism and its implications for Pakistan security: Policy recommendations using exploratory study. IOSR Journal of Humanities and Social Science (JHSS), 4, 19-26. https://doi.org/10.9790/0837-0441926

4. Ahmar, M. (2007). Sectarian conflicts in Pakistan. Pakistan Vision, 9(1), 1-19.

5. Ahmar, M. (2010). Sectarian conflict in Pakistan: Some lessons from the Irish experience. IPRI Journal, 10(1), 50-76.

6. Asad Hashim, (2018). Pakistan's minorities in crosshairs of the latest violence in Quetta. https://www.aljazeera.com/indepth/features/pakistan-minorities-crosshairs-latest-violencequetta18042707430 0008.html

7. Asma, K. M \& Muhammad, K. (2017). History of Sectarianism in Pakistan: Implications for Lasting Peace. $J$ Pol Sci. Pub Aff 5: 291. https://doi.org/10.4172/2332-0761.1000291

8. Bakhsh, R., Khan, S., \& Haider, S. I. (2020). Contesting Sectarian Identity in Pakistan: Narratives from the Three Cities. Global Regional Review, 1, 51-57. https://doi.org/10.31703/grr.2020(V-I).07

9. Basit, A. (2013). The Expansion of Sectarian Conflict in Pakistan. Counter Terrorist Trends and Analyses, 5(4), 14-16. 
10. Grim, B. J. (2014). Religious Hostilities Reach Six-Year High. Pew Research Center, January 14, 2014, http://www.pewforum.org/2014/01/14/religious-hostilities-reach-six-year-high/

11. Hyder, S., Akram, N., \& Padda, I. U. H. (2015). Impact of terrorism on economic development in Pakistan. Pakistan Business Review, 839(1), 704-722.

12. Human Rights Commission of Pakistan. (2014). Stats. Human Rights Commission of Pakistan. http://hrcpweb.org/publication/wp-content/uploads/2019/04/State-of-Human-Rights-in-2018-English.pdf

13. Kalin, M., \& Siddiqui, N. (2014). Religious Authority and the Promotion of Sectarian Tolerance in Pakistan (Vol. 21): 35-47 US Institute of Peace.

14. Kashif, H., (2019). Terror Occurrences in Pakistan: Is it in Waves or Strains? Pakistan Journal of Terrorism Research, I(II), 38-49.

15. Kfir, I. (2014). Sectarian violence and social group identity in Pakistan. Studies in Conflict \& Terrorism, 37(6), 457-472. https://doi.org/10.1080/1057610X.2014.903374

16. Khan, A. U. (2005). The terrorist threat and the policy response in Pakistan. Stockholm International Peace Research Institute.

17. Mahsood, A. K., \& Muhammad, K. (2017). History of sectarianism in Pakistan: Implications for lasting peace. Journal of Political Sciences \& Public Affairs, 5(4), 2. https://doi.org/10.4172/2332-0761.1000291

18. Majeed, G., \& Hashmi, R. S. (2014). Sectarian Conflicts: A dominant threat to Pakistan's Internal Security. Journal of Political Studies, 21(1). 103-118.

19. Malik, Z. U. A., Zhilong, H., \& Ashraf, D. (2019). Terrorism: The Biggest Security Challenge to the Integrity of Pakistan. Orient Research Journal of Social Sciences, 4(1), 96-106.

20. Mishra, V. K. (2004). Madrasas And Sectarian Violence In Pakistan. World Affairs: The Journal of International Issues, 8(3), 41-57.

21. Naaz, S. (2019). Emergence Of Sectarian Violence In Pakistan. 4D International Journal of Management and Science, 10(1), 22

22. Naveed, A., Hussain, A., \& Salim, A. (2011). Connecting the Dots: Education and religious discrimination in Pakistan: A study of public schools and madrasahs. accessed October 12, 2020, http://www.uscirf. gov/sites/default/files/resources/Pakistan-ConnectingTheDots-Email\%283\% 29.pdf

23. Shah, M. N. (2014). Evolution of sectarianism in Pakistan: A threat to the state and society. South Asian Studies, 29(2), 441-459.

24. Shah, M. N. (2014). Evolution of sectarianism in Pakistan: A threat to the state and society. South Asian Studies, 29(2), 441-459.

25. Shaista, M., \& Shafqat, M. A., (2018). Content analysis of hate-speech discourse in religious publications in punjab, pakistan, Journal of Contemporary Studies, VII (1), 38-48

26. Siddiqui, N. (2015). Sectarian Violence and Intolerance in Pakistan. Retrieved September 11, 2017.

27. Smith, C. (2014). Disruptive religion: The force of faith in social movement activism. Routledge. https://doi.org/10.4324/9781315022147

28. Waseem, M., Kamran, T., Ali, M. A., \& Riikonen, K. (2010). Dilemmas of pride and pain: sectarian conflict and conflict transformation in Pakistan. http://www.religionsanddevelopment.org/

29. Wibisono, S., Louis, W. R., \& Jetten, J. (2019). A multidimensional analysis of religious extremism. Frontiers in psychology, 10, 2560. https://doi.org/10.3389/fpsyg.2019.02560

30. Zaman, S., Burfat, G. M., \& Yaseen, M. (2019). The Role of Madrasas in Sectarian Violence: An Empirical Study of Karachi. International Journal of Humanities and Cultural Studies (IJHCS), 6(3), 91-104. 